\title{
SDS-dependent cleavage of nuclear DNA into high molecular weight DNA fragments: a signal to the engagement of apoptosis?
}

\author{
V. T. Solov'yan
}

Institute of Molecular Biology and Genetics Ukrainian Academy of Sciences 150 Zabolotnogo str., 252143, Kyiv, Ukraine

\begin{abstract}
In this paper we employed an extraction of the cells with high concentration of sodium chloride (a procedure commonly used for preparation of histone-depleted nuclei) to investigate the genesis of nuclear $D N A$ degradation during apoptosis. We demonstrated that apoptosis in primary culture of murine thymocytes and in continuously growing Swiss $3 T 3$ fibroblasts is associated with progressive disintegration of huclear DNA into high molecular weight (HMW) DNA fragments of about $50-150 \mathrm{~kb}$ followed by the development of oligonucleosomal DNA ladder. In apoptotic cells both HMW-DNA cleavage and internucleosomal DNA fragmentation can be detected either by cell treatment with ionic detergents (SDS) or by extraction with high concentration of sodium chloride. However, at the early stage of apoptosis only SDS-rietected HMW-DNA cleavage can be observed which precedes the sodium-chloride-detected nuclear DNA degrudation. SDS-detected but not sodium-chloride-detected formation of HMW-DNA fragments occurs in apoptotic cells as early as before detachment. It may be observed also in nonapoptotic cells after they reach the conjluent state and is reversible. On the basis of ohtained results it is possible to suggest that SDS-detected IIMW-DNA cleavage represents a physiological reaction of alive cells that accompanies an curly commitment step of upoptosis.
\end{abstract}

Introduction. Apoptosis is a genetically regulated form of cell death, in which superfluous or abnormal cells are eliminated from an organism $11 \mathrm{l}$. Apoptosis (also referred to as a programmed cell death) plays a fundamental role in cell homeostasis and in a variety of physiological and pathological processes $[2,3]$. Although apoptosis occurs in diverse cell types and is triggered by a number of extracellular and intracellular signals it involves the uniform morphological changes of the cells such as chromatin condensation, cytoplasmic vacuolization and plasma membrane blebbing $\{2\}$. The morphological alterations of apoptosis are accompanied by a variety of biochemical changes. Elevations in cytosolic free calcium (rew 14]) and cytosolic hydrogen ions [5] are followed by internucleosomal DNA degradation $16,7 \mid$ and sharp decreases in cellular NAD levels $|8-10|$. Despite considerable effort has been directed toward defining the biochemical basis for morphological changes associated with apoptosis, no consensus has been achieved. Activation of endonuclease which preferentially

(C) Y. T SOLOVYAN, 1997 cleaves DNA at internucleosomal regions has been considered as a critical event in apoptosis for many years [2, 3]. More recently, the attention of many laboratories has been focused on another essential step of apoptosis, namely, activation of proteases [rews 11,12 ].

In the early phases of apoptosis peculiar modifications of nuclear morphology become evident. Morphological nuclear changes typical for apoptosis usually coincide with double-strand cleavage of DNA at internucleosomal sites $[2,3]$. Recent evidence suggests, however, that the changes in nuclear morphology observed during apoptosis seem to be more closely correlated with the proteolysis of a subset of nuclear proteins $|13-18|$ and the onse1 of high molecular weight (HMW) DNA fragmentation, an event that has been shown to precede $[19-22]$, or, in some cell types, to occur in the absence of internucleosomal DNA cleavage $\{23-25\}$. The formation of HMW-DNA fragments, possibly resulted from the cleavage of looped DNA domains at the attachment points on the nuclcar scaffold, and the activation of proteases, which seem to act in parallel 
with nucleases $[16-18]$, have been postulated to be an early critical event in apoptosis.

Although considerabie progress has been achieved in understanding the biochemical events, underlying morphological changes in apoptotic cells, remarkably few is known about initiating events that trigger apoptotic cell death. The observation that apoptosisrelated cytoplasmic changes can be achieved in enucleated cells $[26,27]$ suggests that nuclear events are not essential for initiation of apoptosis. Genotoxic damage, however, is a powerful apoptotic stimulus, and it secms likely that the nucleus contains important mediators which can initiate apoptotic cascade, at least for particular apoptotic inducers.

In this paper we employed a procedure of cell extraction with high concentration of sodium chloride to monitor the integrity of nuclear DNA during apoptosis and demonstrated that before the formation of HMW-DNA fragments, revealed in sodium-chloride-extracted cells, the «hidden» HMW-DNA cleavage takes place in apoptotic cells, that can be detected by cell treatment with SDS. SDS-dependent HMW-DNA cleavage in apoptotic cells occurs at the early stage of apoptosis, is observable in the densityarrested nonapoptotic cells, and is reversible.

Experimental Procedures. Cell lines and culture conditions. Murine thymocytes obtained from the thymus of a $4-5$ week old mouse (line BALB/C) and Swiss 373 fibroblasts were used for this investigation. 3T3 fibroblasts were routinely incubated in DMEM medium supplemented with $10 \%$ fetal calf serum (FCS) in an atmosphere of $95 \%$ air, $5 \% \mathrm{CO}_{2}$ to give a final suspension of $5 \cdot 10^{\circ} \mathrm{cells} / \mathrm{ml}$. Apoptosis in exponentially growing $3 \mathrm{~T} 3$ fibroblasts was induced by serum withdrawal. Thymocytes primary cultures were prepared from intact thymocytes to give a final suspension of $5 \cdot 10^{\circ} \mathrm{cells} / \mathrm{ml}$ in RPMI $1640 / 10 \%$ FCS and incubated under conditions indicated above for at least $6 \mathrm{~h}$ either with or withou1 $1 \mathrm{mM}$ dexamethasone.

Morphological examination of cells. Cells were harvested by centrifugation and resuspended in $100 \mu \mathrm{l}$ of phosphate buffered normal saline (PBS) at $\approx 10^{7}$ cells $/ \mathrm{ml}$ followed by staining with $1 \mu \mathrm{g} / \mathrm{ml}$ of Hoechst 33342 for $30 \mathrm{~min}$ at $37^{\circ} \mathrm{C}$. After washing cells were resuspended in $30 \mu \mathrm{l}$ of PBS and fixed with $30 \mu \mathrm{l}$ of $4 \%$ paraformaldchyde. For inspection of chromatin $10 \mu 1$ aliquots were laid on glass slides coated with 3-aminopropyl-tricthoxysilane. Microscopy was performed under conditions of normal illumination and fluorescent light using phase contrast optics.

DNA analysis in cellular preparations. $200 \mu \mathrm{l}$ of thymocytc suspension containing app. $1 \cdot 10^{6}$ cells were placed into the well of cell culture plate and equal volume of $1 \%$ low-melting point agarose in PBS-buffer preheated to $37{ }^{\circ} \mathrm{C}$ was added. For preparation of
DNA samples from 3T3 fibroblasts cultural medium was collected and detached cells were harvested from the cultural medium by centrifugation. Attached cells were scraped in the fresh medium and collected by centrifugation. Both attached and detached cells were resuspended in $200 \mu \mathrm{l}$ of the fresh medium and embedded into agarose by addition of preheated to $37{ }^{\circ} \mathrm{C}$ equal volume of $1.5 \%$ low-melting point agarose prepared on PBS-buffer. Agarose-embedded cells (both thymocytes and fibroblasts) were either treated with the lysing buffer (PBS-buffer containing $10 \mathrm{mM}$ EDTA, $1 \%$ SDS) for $1 \mathrm{~h}$ at $25{ }^{\circ} \mathrm{C}$ or with the extraction buffer $(20 \mathrm{mM}$ tris- $\mathrm{HCl}, \mathrm{pH} 7.5,1 \mathrm{mM}$ EDTA, $0.2 \mathrm{mM}$ PMSF, $2 \mathrm{M} \mathrm{NaCl}$ ) three times for 20 min at $4{ }^{\circ} \mathrm{C}$. Both SDS-treated and sodium-chlorideextracted embedded in agarose cells were washed three times for $20 \mathrm{~min}$ at $25{ }^{\circ} \mathrm{C}$ with washing buffer (extraction buffer without $\mathrm{NaCl}$ ) and subjected to electrophoresis.

Agarose gel electrophoresis Agarose plugs with SDS-treated- and sodium-chloride-extracted cells were subjected to conventional or field inversion gel (FIGE) electrophoresis. Conventional gel electrophoresis was carried out in $1.2 \%$ agarose at $70 \mathrm{~V}$ for 3-4 $h$ using $0.5 \times$ TBE buffer $(0.089 \mathrm{M}$ Tris, $0.089 \mathrm{M}$ boric acid, $0.002 \mathrm{M}$ EDTA, $\mathrm{pH} 8.5$ ). As a molecular weight marker was used $1 \mathrm{~kb}$ ladder, obtained from Life Technologies. FIGE was performed in $1 \%$ agarose at $85 \mathrm{~V}$ for $18 \mathrm{~h}$ in $0.5 \times$ $\times$ TBE buffer under constant pulses of electric ficid (24 $s$ «forward» and $8 \mathrm{~s}$ «backward») allowing resolution of DNA molecules sized up to $500 \mathrm{~kb}$ [47]. In some cases FIGE was carried out for $5-6 \mathrm{~h}$ allowing resolution of both low- and high molecular weight DNA. After electrophoresis, the gcl was stained with $1 \mu \mathrm{g} / \mathrm{ml}$ ethidium bromide for $10 \mathrm{~min}$, viewed using a UV transilluminator and photographed using Micrat 300 film.

Results. Data presented in Fig. 1 show that dexamethasone-induced apoptosis in primary culture of thymocytes is associated with an extensive cleavage of nuclear DNA into high molccular weight (HMW) DNA fragments of about $300 \mathrm{~kb}$ and $50-150 \mathrm{~kb}(300$ kb-DNA fragments represent an compression artifact under FIGE employed, results not shown). Parallel fractionation of SDS-treated apoptotic cells both by field-inversion- and conventional gel electrophoresis indicates that the formation of HMW-DNA fragments takes place at the early stage of apoptosis (Fig. 1), and precedes the internucleosomal DNA fragmentation, which represents a hallmark of apoptosis in these cells.

As is evidenced from the results presented in Fig. 2 the typical pattern of nuclear DNA disintegration in apoptotic thymocytes can be detected either by treatment of agarose-embedded cells with ionic detergent 


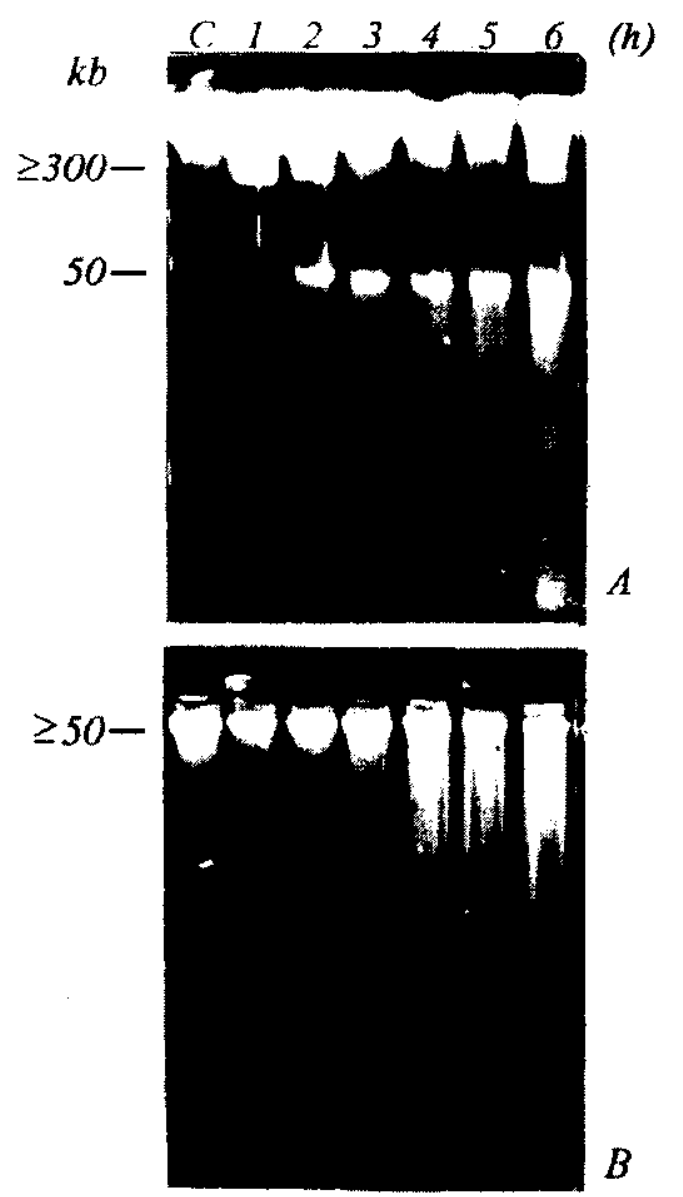

Fig. I. The pattern of melear lNA cleavage in murine thymocytes induced to undergo apoptosis with dexamelhasone. Intac1 murino thymocytes were resuspended in RPM medium supplemented with $10 \%$ FBS and allowed to incubate for $1-6 h$ in the presence of 1 $\mu \mathrm{M}$ deximethasonle. $\Lambda 1$ different time points the samples of the cells were embedded in low-melting agarose as described in Experimental procedure. Agarose-enobedded cells were treated with $1 \%$ SDS for 1 h at $37^{\circ} \mathrm{C}$ and fractionated tither by FIGF (Panel $A$ ) or by conventional gel electrophoresis (pancl $B$ ). $(\therefore$ control cells, nontreated with dexamethasinge

SDS or by cell extration with high concentration of sodium chloride a procedure conmonly used for preparation of histone-depleted nuclei). However, the formation of SDS-defected HMW-DNA fragments in apoptotic thymocyles precedes the nuclear DNA fragmentation detecled by high-salt-extraction (Fig. 2, A). Incubation of primary thymocyte culture without apoptotic inducers atiso results in similar pattern of nuclear DNA disintegration, which involves the formation of HMW-DNA fragments and concomitant development of oligonucleosomal DNA ladder (Fig. 2,
$B)$. This indicates that isolated thymocytes are committed to death, and die via apoptosis even in the absence of apoptotic inducers. At the same time the formation of HMW-DNA fragments to occur rapidly in the cells committed to apoptosis can be detected only in SDS-treated- but not in high-salt-extracted cells, while the oligonucleosomal DNA ladder can be detected by both cell treatment with SDS and extraction with high concentration of sodium chloride (Fig. 2, B). The examination of nuclear morphology by Hoechst 33342-staining reveals that internucleosomal DNA fragmentation accompanies the apoptotic changes in nuclear morphology, while the SDSdetected HMW-DNA cleavage is not associated with the apoptosis-related chromatin changes (Fig. 2).

Data presented in Fig. 3 show that SDS-detected HMW-DNA cleavage in apoptotic thymocytes is reversible after brief heat treatment of the cells. The reversibility of HMW-DNA cleavage is observed at the early stage of apoptosis with its subsequent loss at the advanced stage coinciding with the development of oligonucleosomal DNA ladder (Fig. 3).

The absence of HMW-DNA cleavage in SDS-non-treated thymocytes as well as reversibility of HMWDNA cleavage at the early stage of apoptosis allow us to suggest that SDS-detected HMW-DNA clcavage is not associated with the apoptotic DNA degradation but represents an early genomic event in cells predisposed to undergo apoptosis. To further investigate the relationship between the HMW-DNA cleavage and apoplotic DNA degradation we cxamined the integrity of nuclear DNA in continuously growing Swiss 3T3 cells induced to undergo apoptosis by scrum deprivation. To facilitate the DNA analysis a conventional gel-electrophoresis has been used instead of FIGE since it allows to detect exisily both internucleosomal and HMW-DNA fragmentation (latter is detected as a single condensed band sized about $50 \mathrm{~kb}$, Fig. 1).

Data presented in Fig. 4 demonstrate that the progressive accumulation of HMW-DNA fragments and concomitant development of oligonuclcosomal ladder. detected either by cell treatment with SDS or extraction with sodium chloride, is restricted to the detached serum-deprived 3 T 3 cells. In attached cells, however, there is no obvious sodilim-chloride-detected DNA fragmentation but SDS-detected HMW-DNA cleavage may be observed. These data indicate that the formation of SDS-detected HMW-1)NA fragments in apoplotic 3T3 cells precedes sodium-chloride-detected HMW-DNA cleavage and occurs in alive (attached) cells committed to undergo apoptosis.

From the dati presented at Fig. 5 it is seen that the SDS-detected formation of HMW-DNA fragments takes place in allached 3T3 cells in the absence of apoptotic inducers, with the maximal efficiency of fragmentation being in confluent cells. At the same 


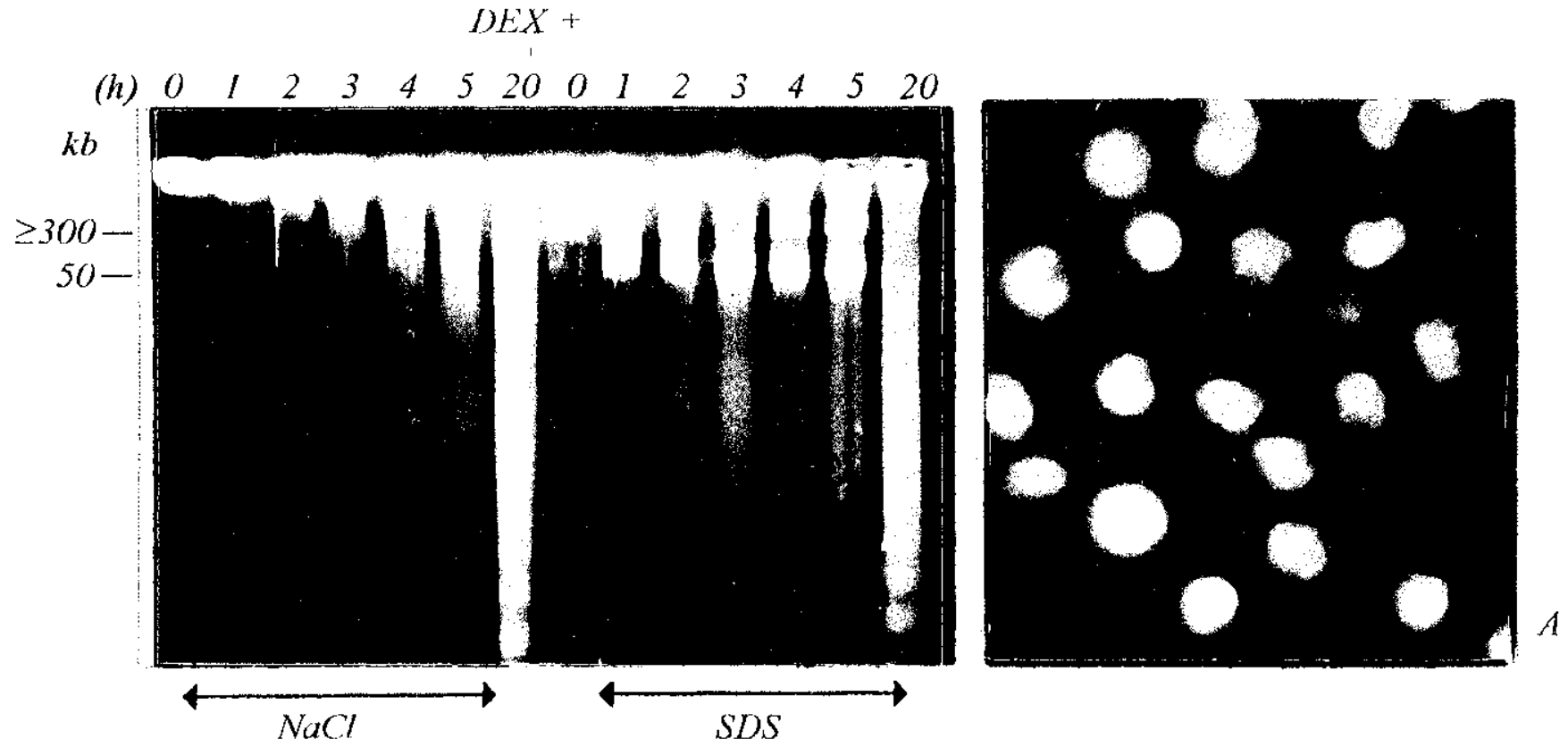

D)EX -
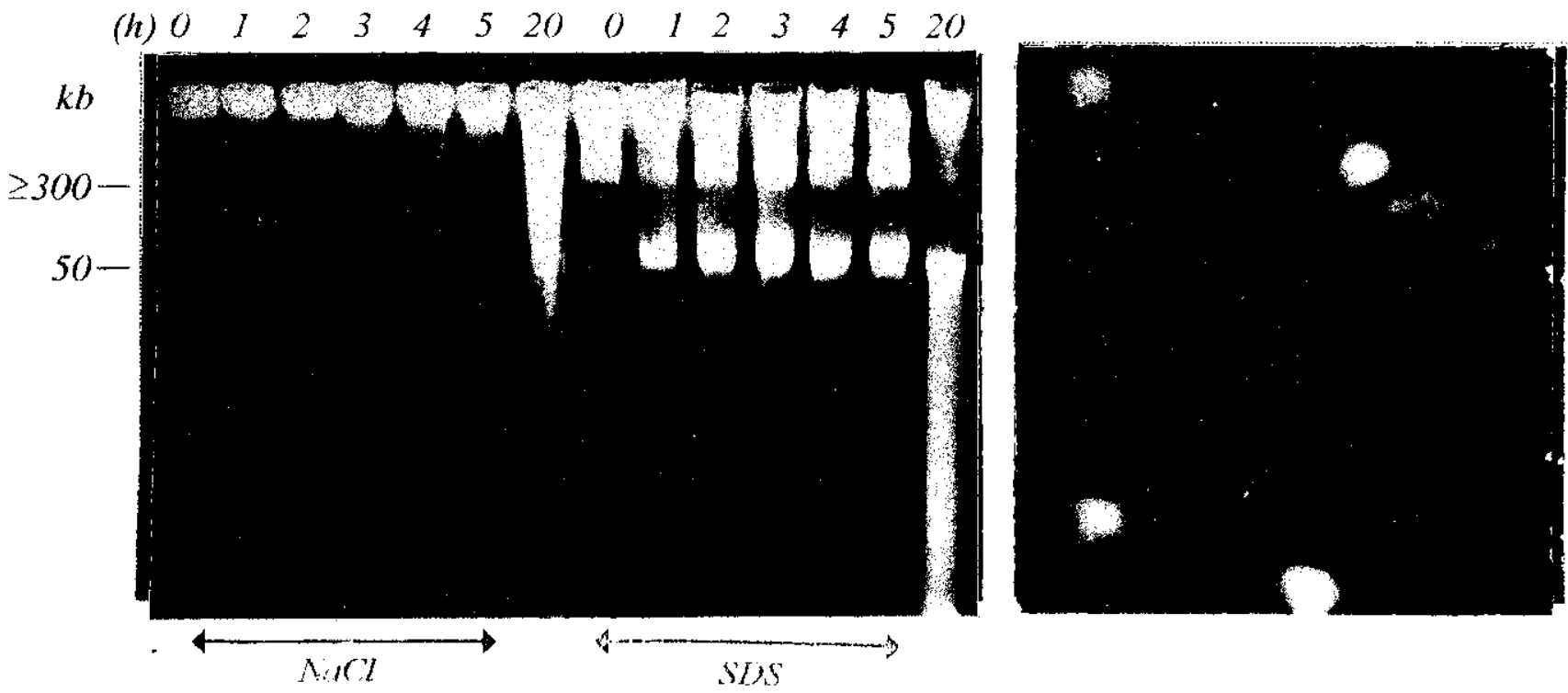

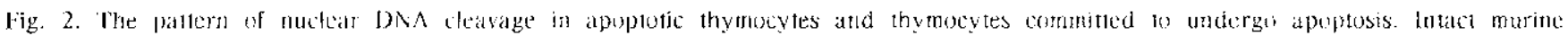

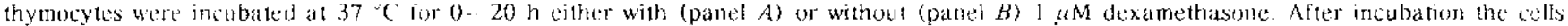
were embedded in low-melling agarose as dexcribed in Experimental Procedure and then were extated either with $2 \mathrm{M}$ NaCl on theated with

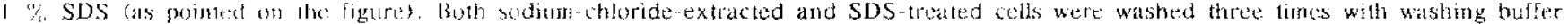

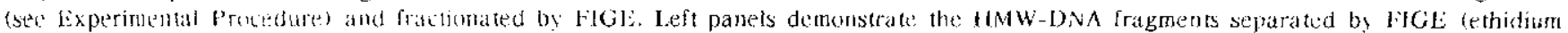

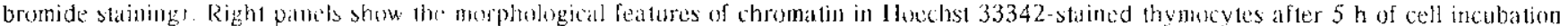




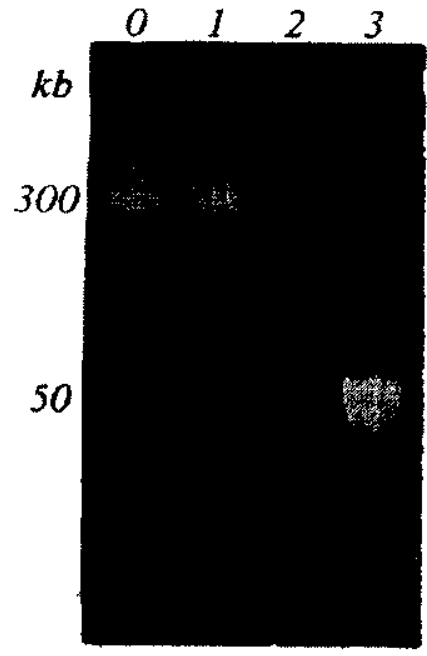

$A$

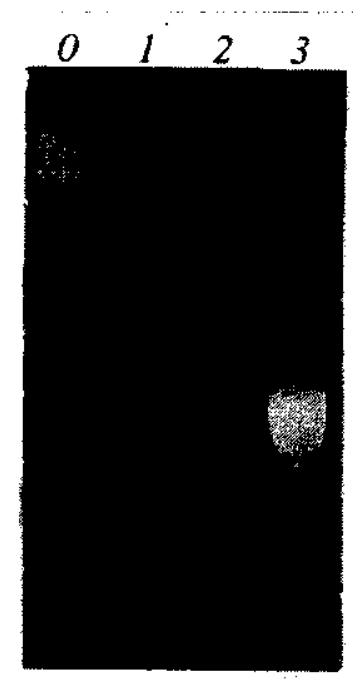

$B$

Fig. 3. The reversibility of HMW-DNA deavage in thymocytes at the early stages of apoptessis. Thymocytes were treated with $1, \mu \mathrm{M}$ dexamethasone and allowed to incubate for $(0-3 \mathrm{~h}$. $\Lambda \mathrm{l}$ different time points cells wert embedded into agarose as described in Experimental Procedures (panel A) or were additionally incubated at $55^{\circ} \mathrm{C}$ for $10 \mathrm{~min}$ followed by agarose embedding (panel $B$ ). After gelation cells were trealed with SDS and fractionaled by $P$ IGE as described in Experimenlal Procedures

time in detached cells, which appcar after monolayer has been established in attached cells, the HMWDNA cleavage can be revealed by both cell treatment with SDS and extraction with sodium chloride (Fig. 5, B).

Data presented suggest that SDS-detected formation of HMW-DNA fragments represents a physiological reaction of alive cells that accompanies changes in functional activity of the cells during the cell passage.

Discussion. Our results show that apoptosis in primary culture of murine thymocytes and in continuously growing $3 \mathrm{~T} 3$ fibroblasts is accompanicd by an ordered fragmentation of nuclear DNA. Two stages of nuclear DNA disintegration can be distinguished in apoptotic cells: the formation of HMWDNA fragments followed by the development of oligonucleosomal DNA ladder (Fig. 1, 4). At the same time our data indicate that there are two types of HMW-DNA cleavatge in cells induced to undergo apoptosis, namely, the HMW-DNA cleavage detected either with $\mathrm{NaCl}$ or SDS and that detected only by cell treatment with SDS.

Because most of the histones and non-histone proteins are extristed upon treatunent of cells with

(h) high concentration of sodium chloride $[28-34]$ one can expect that ds DNA breaks should be revealed in high-salt-extracted cells. As an illustration both HMW-DNA fragments and oligonucleosomal DNA ladder can be detected in high-salt-extracted cells at the aldvanced stage of apoptosis (Fig. 2, 4) and is

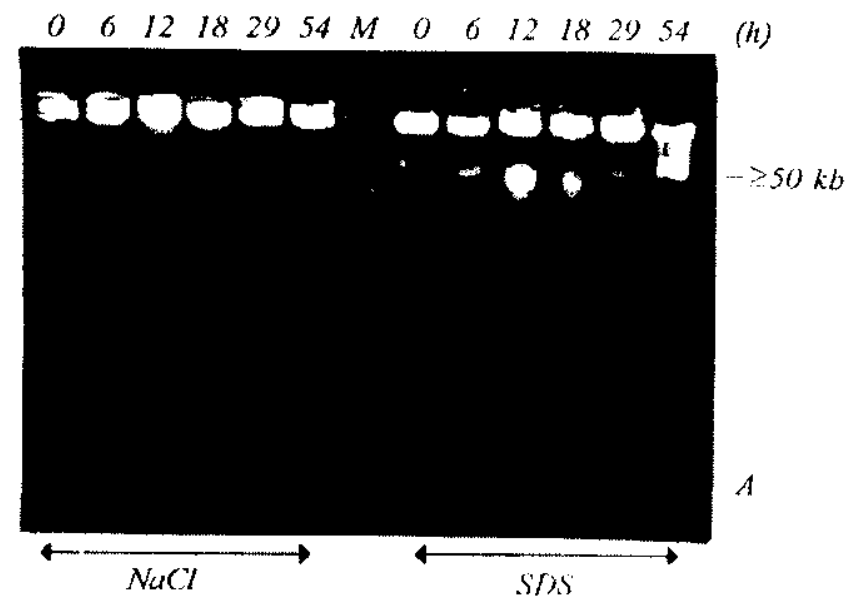

$\begin{array}{llllllllllllll}0 & 6 & 12 & 18 & 29 & 54 & 0 & 6 & 12 & 18 & 29 & 54 & M & (h)\end{array}$

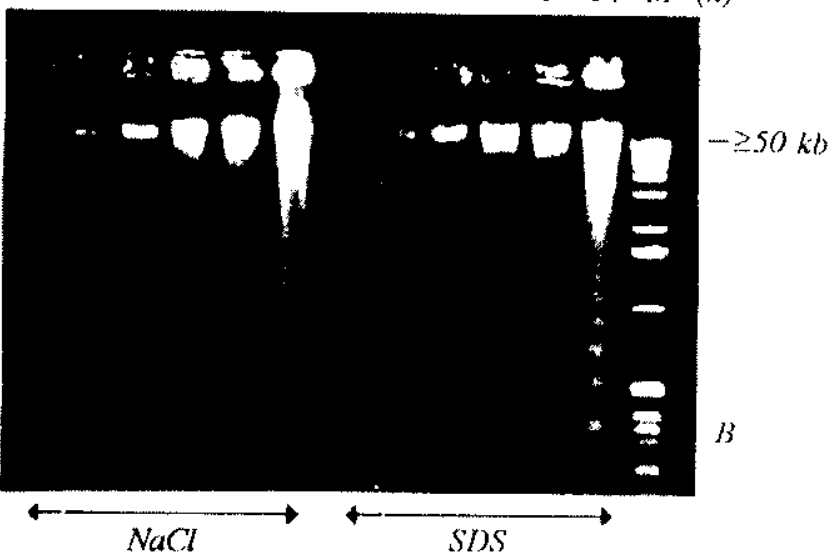

Fig. 4. The pattern of HMW-DNA fragmentation in attached (panel $A)$ atd detached (panel $B$ ) $3 T 3$ fibroblasts induced to undergo apoptosis by serutn deprivation. Exponentially growing cells $(50 \%$ of monolayer) were incubated in serum-deficien medium for 0--54 b. Following incubation the cultural medium was collected and delached cells were harvested from the cultural medium by cest. trifugalion. Altached cells were scraped in the fresh serum-deficient medium and collected by centrifugation. Both attahed and detached cells were embedded inlo agarose as described in Jixperimental Procedures followed by exiraction either with $2 \mathrm{M} \mathrm{NaCl}$ or $1 \%$ SDS. Both sodiunt-chtoride. and SDS-extracted cells were washed three times with washing buffer (see Expcrimental Procedure) followed by fractionation by comventional get elecormphoresis. M, molecular weight slandard, I kb-IDYA ladder 


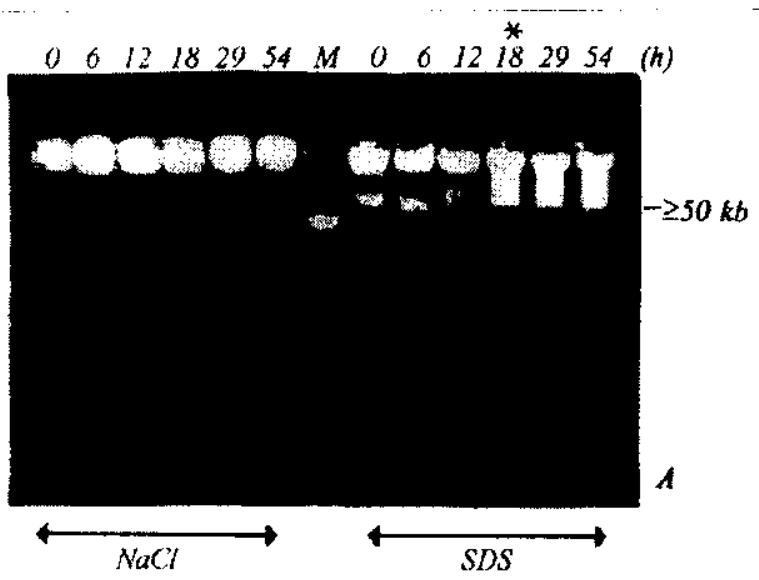

$\begin{array}{lllllllllllll}0 & 6 & 12 & 18 & 29 & 54 & M & 0 & 6 & 12 & 18 & 29 & 54\end{array}$ (h)

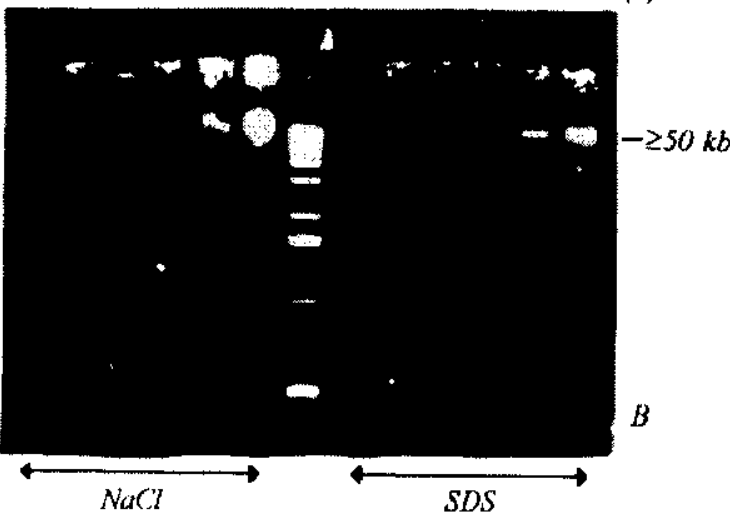

Iig. 5. The pattern of luMW-DNA fragmentation in $3 T 3$ fibroblasts in the absence of apuptotic inducers. The conditions of experiment and the designations are the same as described in the legend to Fig. 4 with the only difference that cells were incubated in serumcontaining mediun. Asterisk indicates the time point when monolayer has been established

further confirmed by the results of Lichtenstein et al. [57] that treatment of isolated nuclei with DNAse I releases the nuclear DNA upon extraction of nuclei with $2 \mathrm{M} \mathrm{NaCl}$. The absence of the HMW-DNA cleavage in high-salt-extracted thymocytes, cultured in vitro without apoptotic inducers, as well as in thymocytes at the early stage of dexamethasoneinduced apoptosis (Fig. 2) clearly indicate that there are no preexisting ds DNA breaks in the cells committed to undergo apoptosis or at the early stage of apoptosis. At the same time the detection of HMW-DNA cleavage in the same cells by cell treatment with SDS suggests that the HMW-DNA cleavage is either induced or revealed by addition of detergent. SDS-dependent formation of HMW-DNA fragments makes the phenomenon observed strikingly analogous to the topoisomerase II-dependent DNA cleavage. This is further confirmed by the observation that SDS-detected HMW-DNA cleavage at the early stage of dexamethasone-induced apoptosis in murine thymocytes is reversible under conditions that favor topoisomerase II-dependent rejoining reaction |58 | (Fig. 3). It is of interest that the reversibility of SDS-detected HMW-DNA cleavage in dexamethasone-treated thymocytes is lost at the advanced stage of apoptosis, when oligonucleosomal DNA ladder is developed (Fig. 3). This suggests that different nucleases may be involved in the HMW-DNA cleavage al the different stages of apoptosis. Alternative explanation is that apoptosis-related proteolysis of 1opoisomerase II $[24,48]$ could underlie the loss of reversibility of HMW-DNA cleavage at the advanced stage of apoptosis.

The examination of nuclear DNA disintegration in $3 \mathrm{~T} 3$ fibroblasts, induced to undergo apoptosis by serum deprivation, allows us to divide several stages of apoptotic DNA fragmentation as follows. SDSdetected formation of HMW-DNA fragments proceeds in attached cells at the early stage of apoptosis, then the detachment of the cells takes place, which is associated with the sodium-chloride-detected HMWDNA cleavage, followed by the development of oligonucleosomal DNA ladder. In the consecutive events of apoptotic DNA degradation to occur in $3 T 3$ cells the appearance of sodium-chloride-detected HMW-DNA fragments seems to be attributed to the detached (dead) cells (Fig. 4). At the same time the SI)Sdetected HMW-DNA cleavage, which precedes the sodium-chloride-detected formation of HMW-DNA fragments in apoptotic thymocytes (Fig. 2), occurs in attached serum-deprived 3 T3 cells (Fig. 4) as well as in the confluent serum-non-deprived cells (Fig. 5). Furthermore, the SDS-detected HMW-DNA cleavage is reversible at the early stages of apoptosis upon brief heat treatment of the cells (Fig. 3) and after addition of the serum to the serum-deprived cells $149 \mathrm{l}$. All these data suggest that SDS-detected formation of HMW-DNA fragments shares no common feature with an apoptotic DNA degradation but represents an early genomic event in cells committed to undergo apoptosis. Indeed, there is no difference in the ability to SDS-detected formation of HMW-DNA fragments both in atlached serum-deprived cells (preapoptotic cells) and serum-non-deprived (healthy) cells (compare Fig. 4 and 5). Remarkably, an increased formation of SDS-detected HMW-DNA fragments takes place in cells stimulated to undergo apoptosis by non-genotoxic inducers, namely by dexamethasone, and by serum deprivation. This indicates that the nucleus contains important mediators of the carly events of apoptosis even in the absence of DNA damaging agents.

It is becoming increasingly evident that apoptosis 
occurs in response to many different stimuli, of which a partial list includes withdrawal of growth factors, inappropriate expression of genes that stimulate cell cycle progression, and viral infection. Several of these factors have in common the property that they alter the cell cycle, and it has been proposed that apoptosis primarily reflects a cell cycle perturbation $[50,51]$. Becausc the most probable event accompanying a cell engagement to apoptosis might be an arrest of cell proliferation one could assume that SDS-detected formation of HMW-DNA fragments reflects changes in proliferative status of the cells. This is further confirmed by the data that monolayer establishment in continuously growing $3 \mathrm{~T} 3$ cells is accompanied by an increased formation of SDS-detected HMW-DNA fragments (Fig. 6). On the other hand, the stimulation of confluent cells to proliferation by dilution of monolayer is accompanied by decreased HMWDNA cleavage [49]. These data allow us to suggest that an arrest of cell proliferation may underlie the formation of SDS-detected HMW-DNA fragments, an event that secms to represent an early commitment step to the subsequent apoptosis.

The cleavage of nuclear DNA into HMW-DNA fragments to occur at the early stage of apoptosis (or at the commitment stage of apoptosis) clearly indicate that there is a periodic location of cleavage sites along genomic DNA. It is becoming apparantly evident that in the interphase nucleus each chromosome occupies its own threc-dimensional space due to the established contacts with the protein scaffold to generate a complex structural organization. An extraction of nuclei with high concentration of sodium chloride reveals that nuclear DNA is organized into topologically constrained loop domains anchored to a protein backbone structure referred to as the nuclear matrix or chromosome scaffold [28-34].

Topoisomerase II has been shown to be a major component of the nuclear matrix and plays an important role in chromosome structure and dynamics |35-37|. Several lines of evidence suggest that topoisomerase $I I$ is concentrated in a number of discrete anchoring complexes which probably form the bases of the chromatin loop domains $[35,38-40$, rew 41,42 ].

Previously we demonstrated that the HMW-DNA fragments, resulted from the treatment of nuclear DNA preparations with the protein-denaturing agents, correspond to DNA loop domains 152]. The relation of $H M W-D N A$ fragments to the DNA loop domains were also concluded by other authors $[53$, 541 . We presented evidence indicating that DNA loop domains in nonapoptosizing tissues are involved in functional topoisomerase II/DNA complexes with the ability to mediate the clcavage/rejoining reactions $[55,56]$. Based on studies with purified topo II enzymes and DNA, a two-stage model for topo- isomerase $1 \mathrm{l}$-mediated cleavage/religation reactions has been proposed [45, 46]. According to this model, an enzyme/DNA cleavable complex is the key covalent intermediate in the topoisomerase 11 -mediated DNA turnover which is in rapid cquilibrium with the noncleavable complex $[45,46]$. DNA in the cleavable complex is broken, but ds DNA breaks are hidden since they are clamped by topo II enzyme. The exposure of the cleavable complex to protein denaturants such as SDS or alkali results in a cleaved DNA product involving the covalent linking of topoisomerase II subunits to the $5^{\prime}$-ends of broken DNA $[45,46]$.

Proceeding from the results that structural domains of nuclear DNA contribute to the functional topoisomerase IIDNA complex $[55,56]$ it secms appropriate to interpret the SDS-detected HMW-DNA cleavage to occur at the carly stage of apoptosis as a transition of DNA structural domains from «noncleavable» to «cleavable» state, mediated by topoisomerase II. Our results allow us to suggest that changes in the functional properties of the complexes topoisomerase II/DNA structural domains, resulting in altered pattern of HMW-DNA cleavage, may be a physiologically valuable genome reaction, that underlies an early commitment step of apoptotic cell death.

To summarize it can be concluded that changes in the integrity of nuclear DNA, recognizable as an altered pattcrn of SDS-dependent HMW-DNA cleavage, represent a physiological reaction of the cells engaged in apoptosis. This reaction may be associated with changes in proliferative status of the cells and may be interpreted as a Iransition of topoisomerase II/DNA complex between «cleavable» and «noncleavable» states.

I thank Dr. P. Pogrebnoy, for kindly provided cell cultures, Dr. S. Mikholap for help in fluorescent analysis, and Igor Andreev for excellent assistance in conducting of experiments and preparation of inanuscript. This work was supported by the Committee for Fundamental Research at the National Academy of Sciences, Ukraine.

\section{B. T. Солов' $\mathrm{H}$}

DS-Na-залежне розиеплення ядерниі ЦНК па високомолекулярні фрапменти: синнал до початку апитозу?

Pesiome

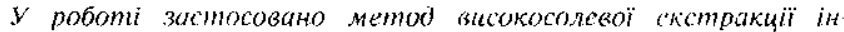
мактних клітин для вивнення динаміки розиеппення ядерної

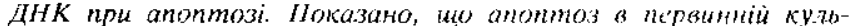

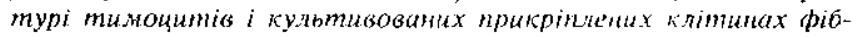

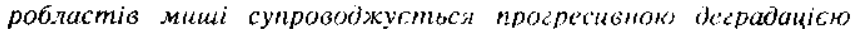
ядерної ДНК на високомолекуляриі фрасиении розиіром 50-150 тис. n. н. 3 подальинм рормуванням олікануклеосомних

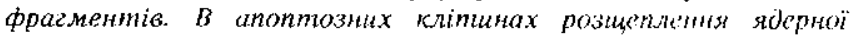


ДНІК на бисокомелькулярні та олігонуклеосомиі фрасменти

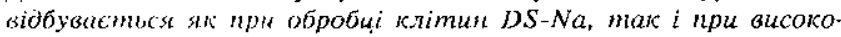

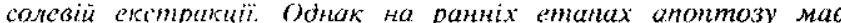
місце лиае DS-Na-залежна високомолекулярна фрагментація ядернӧ̈ ДНК, яка передує формуванню високомолекулярних фрасмениік, ио виявляються при високосолезій екстракціі клітин. На вімміну від розривів, икі виявляктися високосоле зою екстракціск, DS-Na-залежне розицелиення яберной ДНК на високомолеку.лярмі фрасменти спостерігасться в апоптозних

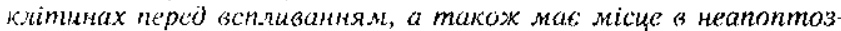
tux кліmmax, uо dосягпи моношару. Показано, що DS-Na-3a-

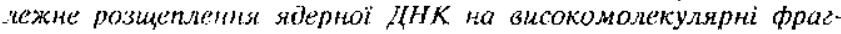
мetmie na hotamкoвux cmadisx anonmosy 6 зворотним в умо зах, ио сприяють залежному від попоізмерази II лігуванню розривів ДНК. Отримані результати свідиамь, що DS-Na-зaлежне розиеплення ядерної ДНК иа високомолекулярні фрагменти с: фiзіллогінною реакціко живих клітин, яка передує anonmoзнiй dezpadakiï sdepної $Д H K$.

\section{B. T. Соловьян}

DS-Na занисимое расщепление ждерізой ДНК на высокомолеку!яриве фрагменты: сигнал к началу апоптоза?

Peзюme

В рабоне нримсн'" метод высокосолевой жкстракиии интактнох кдипок фля нзучения динамики расиепления ядерной ДНК при апоптозе. Показано, что апоптоз в первичной культуре тикоцитов и культияированных прикрепляюиихся клетках ‘ибробластов мынии сопровождается прогрессивной деграда цией ядерноі ДНК на высокомолекуллрные фрагменты разме ром 50-150 moic. и. н. с последующим формированием олиго "уклесомиых фрасментов. $B$ апоптозных клетках расицепление ялерноі ДНК на высокомолекулярнье и олисонукиеосомные фрасменты происходин как при обрабонке клеток $D S-N a$. так и при восокосопевой зкстракции. Ојнако на ранних manax anonmoза useem .месnо nuub DS-Na-завucusar вbicoкомолекулярная фрасментация ядерной ДНК, предиествуюиая формированио высокомолекулярньх фрагментов, вынв ллемых высокосолевой әкстракциеи клеток. $B$ отличие от разрывов, обнаруживаемых высокосолевой зкстракцией, DS-

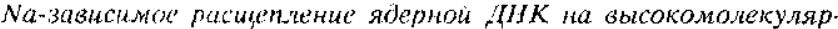

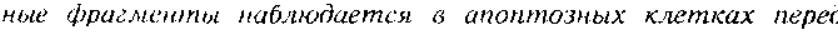
всnльmием, а makже инеен месmо в неапоптозных клетках,

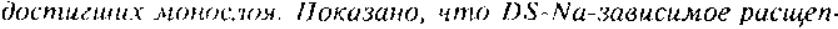
нение sотрной ДНК на вьсокомолекулярные фрагменты на

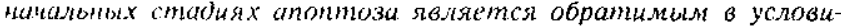

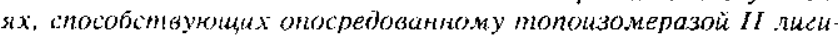

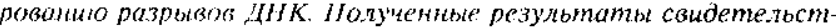

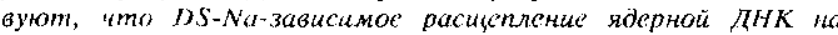
высокомолекулярныс фросиенты предстаяляет собой физиологическую реакцию живых клеток, которая иредиествует

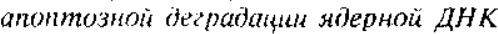

\section{REFERENCES}

i. Ellis R. F., Yuan Y.-Y., Horvitz H. R. Mechanisms and function of cell death // Antu. Rev. Cell Biol.-1991.-7.P. $663-668$

2. Kerr J. F. R., Wyllie A. H., Currie A. R. Apoptosis: a basic biological phenomenon with wide ranging implications in tissue kinctics // Br. J. Cancer. - 1972.-26.-P. 239-257.

3. Wyllie A. H., Kerr J. $I$. R., Currie A. R. Cell death: the significance of apoptosis // Int. Rev. Cytol.-1980.-68.P. $251 \ldots 305$

4. MiConkey O. J., Orrenius S., Jondal M. Cellular signaling in programmed cell death (apoptosis) // Immunol. Today.$1990 . .11 .-$ P. 120-121.
5. Barry M. A., Eastman A. Endonuclease activation during apoptosis: the role of cytosolic $\mathrm{Ca}^{2+}$ and $\mathrm{pH} / /$ Biochem. and Biophys. Res. Communs. -1992 -186. -P. 782-789

6. Caron-Leslie L.-A. M., Schwartzman R. A., Gaido M. L. tt al. Identification and characterization of glucocorticoid-regulated nuclease(s) in lymphoid cells undergoing apoptosis // J. Steroid Biochem. and Mol. Biol.-1991.-48.-P. 661-671.

7. Arends $M$. J., Wyllie A. H. Apoptosis: mechanisms and roles in pathology // Int. Rev. Exp. Pathol. - 1991._32._P. 223254.

8. Das S. K., Berger N. A. Alterations in deoxynucleoside triphosphate metabolism in DNA damaged cells: implication and consequences of poly (ADP-ribose) polymerase dependent and independent processes // Biochem. and Biophys. Res. Communs. -1986,-137.-P. 1153-1158.

9. Berger N. A., Berger S. J., Sudar D. S., Distelhort C. W. Role of nicotinamide adenine dinucleotide and adenoside triphosphate in glucocorticoid-induced cytoroxicity in susceptible lymphoid cells // J. Clin. Invest. - 1987.-79.-P. 1558-1563.

10. Denisenko M. F., Soldatenkov V. A., Belovskaya $I . \quad$ N. Filippovich $I . V$. Is the NAD-poly(ADP-ribose) polymerase system the trigger in radiation-induced death of mouse thymocytes? // Int. J. Radiat. Biol. - 1989.-56. - P. 277285.

11. Patel T., Gores G. J., Kaufmann S. $H$. The role of proteases ouring apoptosis // FASEB J.-1996-10.--P. 587-597.

12. Takahashi A., Earnshaw W. C. ICE-related proteases in apoptosis // Curr. Opinion Genet. and Develop. - 1996.-6.P. $50-55$.

13. Kaufmann S. H., Desnoyers S., Ottaviano $Y$. et al. Specific proteolytic cleavage of poly (ADP-ribose) polymerase: an early marker of chemotherapy-induced apoptosis // Cancer Res. I 993.-S3.-P. 3976-3985.

14. Lasebnik Yu. A., Cole S., Cooke C. A. ct al. Nuclear events of apoptosis in vitro in cell-free mitotic extracts: a model system for atralysis of the active phase of apoptosis $/ / \mathrm{J}$. Cefl Biol.-1993.-123.-P. 7-22.

15. Zweyer $M$., Bureggi $R$., Grill $V$. et al. Behavior of nuclear matrix proteins during camptothecin-induced apoptosis in HL60 human leukemia cells // Exp. Cell Res.-[995.-221.P. $27-40$.

16. Weaver V. M., Carson Ch. E., Walker P. R. et ul. Degradation of nuclear matrix and DNA cleavage in apoptolic thymocytes // J. Cell Sci.-1996. -189.-P. 45--56.

17. Lasebnik Yu. A., Takahashi A., Moir R. D. at al. Studies of the lamin proteinase reveal multiple paraflei biochenical pathways during apoptotic execution // Proc. Nat. Acad. Sci. USA. - 1995. - 92-P. 9042-9046.

18. Hara S., Halicka II. D., Bruno S. et al. Effect of protease inhibitors on early events of apoptosis // Exp. Cell Res.1996.-223.-P. 372-384

19. Oberhammer F., Fritch G., Schmied $M$. et al. Condensation of the chromatin at the membrane of an apoptotic nucleus is not associated with activation of endonuclease // J. Cell Sci.1993.-184.-P. 317-326.

20. Brown D. G., Sun X.M., Cohen $G$. M. Dexamethasone-induced apoptosis involves cleavage of DNA to large fragments prior to internucleosomal fragmentation // J. Biol. Chem.1993.-268.-P. 3037--3039.

21. Walker P. R., Kokileva L., LeBlanc J., Sikorska M. Detection of the initial stages of DNA fragmentation in apoptosis // BioTechniques. - 1993.-15....P. 1032-1040.

22. Cohen $G$. M. Sun X.-M., Foarnhead $H$. ct al. Formation of large molecular weight fragments of DNA is a key commitment step of apoptosis in thymocytes // J. Immunol.-... 1994. - 153.P. $507-516$. 
23. Oberhammer F., Wilson J. W., Dive C. et al. Apoptotic death in epithelial cells: cleavage of DNA to 300 and/or $50 \mathrm{~kb}$ fragments prior to or in the absence of internucleosomal fraginentation // EMBO J.-1993.-12.-P. 3679-3684

24. Beere H. M., Chresta C. M., Alejoherberg A. ct al. Investigation of the mechanism of higher order chromatin fragmentation observed in drug-induced apoptosis // Mol. Pharmacol.1995.-47. -P. 986-996.

25. Cohen G. M., Sun X. M., Snowden R. T. et al. Key morphological features of apoptosis may occur in the absence of intermucleosomal DNA fragmentation // Biochem. J.1992.-286. -P. 331-334.

26. Schulze-Osthoff $K$, Walczak $H$. , Droge W., Krammer P. $H$. Cell nucleus and DNA fragmentation are not required for apoptosis // J. Cell Biol. - 1994.-127.-P. 15-20.

27. Jacobson $M$. D., Burne J. F., Raff M. C. Programmed cell death and $\mathrm{Bcl}-2$ protection in the absence of a nucleus // EMBO J.-1994.--13.-P. 1899--1910.

28. Berezney $R$., Coffey $D$. S. Identification of a nuclear protein matrix // Biochem. and Biophys. Res. Communs.-1974.60.-P. $1410-1417$.

29. Benyajati $C$., Worcel $A$. Isolation, characterization, and structure of the folded interphase genom of Drosophila melanogaster // Cell.-1976.-9.-P. 393-407.

30. Cook P. R., Brazell I. A. Conformational constraints in nuclear DNA // J. Cell. Sci.-1976.-22.-P. 287-302.

31. Adolph $K$. W., Cheng S. M., Laemmli U. K. Role of non-histon proteins in metaphase chromosome structure // Cell. - 1977.-12.-P. 805-816

32. Luemmli U. K., Cheng S. M., Adolph K. W. et al. Metaphase chromosome structure: The roie of nonhistone proteins // Cold Spring Harbor Symp. Quant. Biol. -1978,-42....P. 351360 .

33. Pardoll D. M., Vogelstein B., Coffey $D$. S. A fixed site of DNA replication in eukaryotic cells // Cell. $-1980,-19 .-$ P. 527537

34. Mirkovitch J., Mirault M.-E., Laemmli U.K. Organization of the higher order chromatine loop: specific DNA attachment sites on nuclear scaffold // Ibid.-1984.-39. -P. 223-232.

35. Earnshaw W. C., Heck M. M. S. Localization of topoisomerase Il in mitotic chromosomes // §. Cell. Biol. $-1985 .-100 .-$ P. $1716-1725$.

36. Berrios $M$., Osheroff $N$., Fisher $P$. A. In situ localization of DNA 1opoisomerase $\mathrm{JI}$, a major polypeptide component of Drozophila nuclear matrix fraction // Proc. Nat. Acad. Sci. USA.-1985.-82.-P. 4142-4146.

37. Cockerill P. N., Garrard W. T. Chromosomal toop anchorage of the kappa immunoglobulin gene occurs next to the enhancer in a region containing topoisomerase II sites // Cell - - 1986. 44. - P. 273-..283

38. Gasser S. M., Larche T., Falquet J. ct. al. Metaphase chromosome structure. Involvement of topoisomerase II // J. Mol. Biol._1986 …188,-P. 613-629.

39. Adachi $Y$., Kas E., Laemmli $U$. K. Preferential, cooperative binding of DNA topoisomerase $n$ to scaffold-associate regions // EMBO J.—1989. -8.-P. 3997- 4006.

40. Sperry A. O., Blasquez V. C., Garrard W. T. Dysfunction of chromosomal loop attachment sites: Iltegitimate recombination linked to matrix association region and topoisomerase II // Proc. Nat. Acad. Sci. USA. - 1989.-86.-P. 5497-5501.

41. Gasser S. M., Laemm/i U. K. A glimpse at chromosomal order $1 /$ Trends Genet.--1987.--3.-P. 16-22.
42. Poljak $L ., K a s$ E. Resolving the role of topoisomerase II in chromatin structure and function // Trends Cell Biol... 1995.-5.-P. 348-354.

43. Vosberg H.-P. DNA topoisomerases: enxymes that control DNA conformation // Curr. Top. Microbiol. Immunol.--1985.114.-P. $91-102$.

44. Wang J. C. DNA topoisomerases // Annu. Rev. Biochem.1985.-54...P. $665-697$

45. Osheroff $N$. Biochemical basis for the interaction of type $\mathrm{I}$ and II topoisomerases with DNA // Pharmacol. Ther.-1989.41.-P. 223-241.

46. Lia $L$. F. DNA topoisomerase poisons as antitumor drugs // Arnu. Rev. Biochem.-.-1989.-58.-P. 351-375.

47. Heller C., Pohl F. M. A systematic study of field inversion gel electrophoresis // Nucl. Acids Res.-1989.-17.-P. 59896003.

48. Kaufmann $S$. $H$. Induction of endonucleolytic DNA cleavage in human acute myelogenous leukemia cells by etoposide, camptothecin, and other cytotoxic anticatncer drugs: a cautionary note // Cancer Res.-1989.-49._-P. 5870-5878.

49. Solovyan V. T., Andreev I. O., Kolotova T. Yu. et al. An ordered disintegration of nuclear DNA as a specific genome reaction accompanying apoplosis, stress response and differentiation // Biopolymers and Cell...-1 996, --12, \& 3.-P. 6776.

50. Ucker $D$. S. Death by suicide: one way to go in mammalian cellular development // New Biologist.-1991._3.-P. 103109.

51. Se'n S., D'Incalci $M$. Apoptosis. Biochemical events and relevance to cancer chemotherapy // F\}BS I.ett.-1992.387.-P. 122-127

52. Solov'yan V. T., Andreev I. O., Kunakh V. A. The fractionation of eukaryotic DNA by pulsed field gel electrophoresis. II The discrete DNA fragments and the levels of chromatin structural organization // Molec. Biol. (Russia).-1991.25.-P. 1159-1163.

53. Filipski J., Leblanc J., Youdale $T$. et al. Periodicity of DNA folding in higher order chromatin structure // ISMBO J.1990.-9.-P. 1319-1327.

54. Razin S. V., Hancock R., Iarovaia O. et al. Structural and functional organization of DNA domains // Cold Spring Harbor Symp. Quant. Biol.-1993.-58.-P. 25-35.

55. Solov'yan V. T., Andreev I. O., Kunakh V. A. Functional organization of plan nuclear DNA. I. Evidence for a DNATopoisomerase II complex // Mol. Biol. (Russia).-1993.27.-P. 770-774.

56. Solov'yan V. T., Andreev 1. O. Structural domains of plant nuclear DNA as a constitutive component of topoisomerase II/DNA compiex // Acta biochim. pol.-[995.-42, N 2.-P $201--204$

57. Lichtenstein A. V., Zaboikin M. M., Sjakiste N. I., Alechina $R$. P. Differential dissociation of chromatifi digesis: a novel approach revealing a hierarchy of DNA-proteir interactions within chromatin domains // J. Cell Sci.-1991.-99.P. $503-513$

58. Hsiang Y.-H., Lia $I . \quad F$. Evidence for the reversibility of cetlular DNA lesion induced by mammatian topoisomerase Il poisons // J. Biol. Chem.-1989.-264.-P. 9713 - 9715

Reccived 24.12.96 